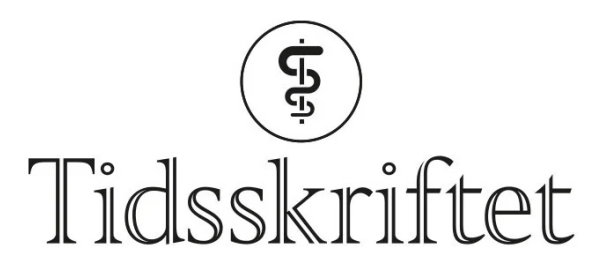

DEN NORSKE LEGEFORENING

\title{
Stressfraktur i calcaneus
}

\author{
KLINISK OVERSIKT
}

\section{ØYVIND ANDERSSEN}

oyvind_anderssen@hotmail.com

Det medisinske fakultet

Universitetet i Oslo

Øyvind Anderssen har bidratt med idé, litteratursøk og illustrasjon samt utforming, revisjon og godkjenning av manuskriptet.

Øyvind Anderssen er medisinstudent.

Forfatteren har fylt ut ICMJE-skjemaet og oppgir ingen interessekonflikter.

\section{LARS ENGEBRETSEN}

Ortopedisk klinikk

Oslo universitetssykehus

og

Seksjon for idrettsmedisinske fag

Norges idrettshøyskole

Lars Engebretsen har bidratt med idé, litteratursøk, utforming, revisjon og godkjenning av manuskriptet.

Lars Engebretsen er dr.med., spesialist i ortopedisk kirurgi, overlege og professor. Han er gruppeleder ved senter for idrettsskadeforskning og leder Den internasjonale olympiske komités medisinske forskningsgruppe.

Forfatteren har fylt ut ICMJE-skjemaet og oppgir ingen interessekonflikter.

\section{ARNE LARMO}

Aleris Røntgen

Arne Larmo har bidratt med revisjon og godkjenning av manuskriptet samt radiologibilder og analyse av disse.

Arne Larmo er spesialist i radiologi og konsulent i radiologi for Aleris og for Olympiatoppen. Forfatteren har fylt ut ICMJE-skjemaet og oppgir ingen interessekonflikter.

\footnotetext{
Stressfraktur i calcaneus (hælbeinet) er en skade som særlig rammer idrettsutøvere og mosjonister ved gjentakende overbelastning av underekstremitetene over tid uten tilstrekkelig restitusjon. Mediale og laterale hælsmerter under aktivitet vekker mistanken, men radiologiundersøkelser kreves for sikker diagnose.
} 


\section{Behandlingen er som regel konservativ, med restitusjon og ernæringskorreksjon. Kun i noen tilfeller er det aktuelt med en farmakologisk eller kirurgisk tilnærming.}

Stressfrakturer, også kalt tretthetsbrudd, skiller seg fra vanlige akutte frakturer ved at de oppstår når bein utsettes for gjentatte mindre kraftige kompresjons- og tensjonskrefter enn det som skal til for å gi et akutt brudd (1). Skaden skyldes unormal belastning av friskt beinvev, med glidende overgang til insuffisiensfrakturer, som oppstår ved normal belastning av svekket beinvev (므).

Stressfraktur i calcaneus ses oftest hos aktive idrettsutøvere og militærrekrutter, men også hos ivrige mosjonister som driver med langrenn og langdistanseløping $(3,4)$. De siste årene har bevisstheten rundt stressfrakturer $\emptyset \mathrm{kt}$, blant annet fordi de ofte henger sammen med spiseforstyrrelser, som forekommer relativt hyppig i idrett både på senior- og juniornivå (5).

Hensikten med denne artikkelen er å belyse stressfrakturer i calcaneus som en differensialdiagnose ved hælsmerter hos idrettsutøvere og mosjonister. Artikkelen er basert på et litteratursøk i PubMed, der 160 artikler og sammendrag fra perioden 1.1.19968.1.2021 ble gjennomlest og 29 ble inkludert. I tillegg bygger artikkelen på andreforfatters kliniske erfaring innen ortopedi og idrettsmedisin og tredjeforfatters erfaring innen radiologi.

\section{Epidemiologi}

Stressfrakturer er sjeldne i normalbefolkningen, men relativt vanlige i idrettsmedisinsk sammenheng ( $\underline{6})$. Forekomsten er hyppigst innen øvelser som innebærer gjentatte bevegelsesmønstre (1), og generelt blant idrettsutøvere er ettårsinsidensen av stressfrakturer 6-21\% (7,,$\underline{8})$. Opptil 90 \% av disse oppstår i underekstremitetene, hvorav ca. $20 \%$ lokaliseres til calcaneus (ㅁ,, 9 .).

\section{Etiologi og patogenese}

Under fysisk aktivitet utsettes knoklene våre for mekaniske krefter som fører til mikrofrakturer i beinvevet. Slike mikrofrakturer vil normalt repareres av en målrettet beinremodelleringsprosess som foregår i sykluser med beinresorpsjon og -nydannelse (22).

I tråd med gjeldende beinremodelleringsteorier vil en økning i varighet, hyppighet eller intensitet av knokkelbelastningen kombinert med utilstrekkelig restitusjon føre til at resorpsjonsaktiviteten overskrider osteoblastenes kapasitet til beinnydannelse, slik at mikrofrakturene akkumulerer i beinvevet. Dette igangsetter reparasjonsprosesser med påfølgende beinmargsødem. Ved ytterligere belastning og mangelfull restitusjon kan det oppstå en stressreaksjon i beinvevet, som til slutt kan progrediere til en stressfraktur med synlig frakturlinje ved bildediagnostikk $(\underline{1}, \underline{10})$. I calcaneus induseres denne prosessen av repetitive kompresjonskrefter og drag fra akillessenen (ㅁ), som ved langdistanseløping, hoppebevegelser (3) og diagonalgang på ski.

Stressfrakturer har betydelig økt morbiditet sammenlignet med stressreaksjoner, noe som gjør tidlig intervensjon viktig $(\underline{10})$. I calcaneus oppstår stressfrakturer perpendikulært på trabeklenes orientering, noe som vil si at bakre frakturer som regel er skråstilte, mens fremre frakturer er horisontale (4). Fremre stressfrakturer i calcaneus er sjeldne og er som regel assosiert med en medfødt calcaneonavikulær sammenvoksning (11) eller lang fremre calcaneus-prosess (므). 
Forut for de fleste stressfrakturer har det vært endringer i treningsregimet (무), men ernæringsforstyrrelser spiller også ofte en rolle. Slike forstyrrelser er ikke uvanlig innen idretter der lav kroppsvekt kan være fordelaktig (5). Dette omtales gjerne som relativ energimangel i idrett (relative energy deficit in sports, RED-S). Utilstrekkelig inntak av kalsium og vitamin D samt lav energitilgjengelighet er assosiert med økt forekomst av stressfrakturer (13-15).

Blant kvinner kan relativ energimangel føre til menstruasjonsforstyrrelser og lave østrogennivåer, som ofte resulterer i en reduksjon av beintettheten $(\underline{16})$. Lav beintetthet har i prospektive studier vist seg å være assosiert med stressfrakturer, særlig i trabekulære knokler som calcaneus $(4,13,17$.). Kvinner har større risiko for å utvikle stressfrakturer enn menn (묘), sannsynligvis grunnet lavere beintetthet og $\emptyset \mathrm{kt}$ forekomst av spiseforstyrrelser (5).

\section{Symptomer og funn}

Hovedsymptomet på stressfrakturer og foregående stressreaksjoner i calcaneus er hælsmerter ved belastning, oftest lokalisert til mediale og laterale rand av hælbeinet (199.). I tidlige stadier kjenner man smertene som regel kun mot slutten av eller etter fysisk aktivitet (3). Forblir skaden ubehandlet, utløses smertene gradvis tidligere under aktivitet,

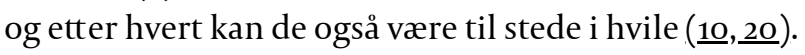

Calcaneusklemmetesten kan fremprovosere smertene i klinisk praksis. Testen utføres ved å klemme sammen den bakre delen av calcaneus i horisontalplanet mellom tommelfingeren og pekefingeren (3) (figur 1). Sensitivitet og spesifisitet for testen er ukjent. I noen tilfeller finner man også hevelse og varme over calcaneus (3). 


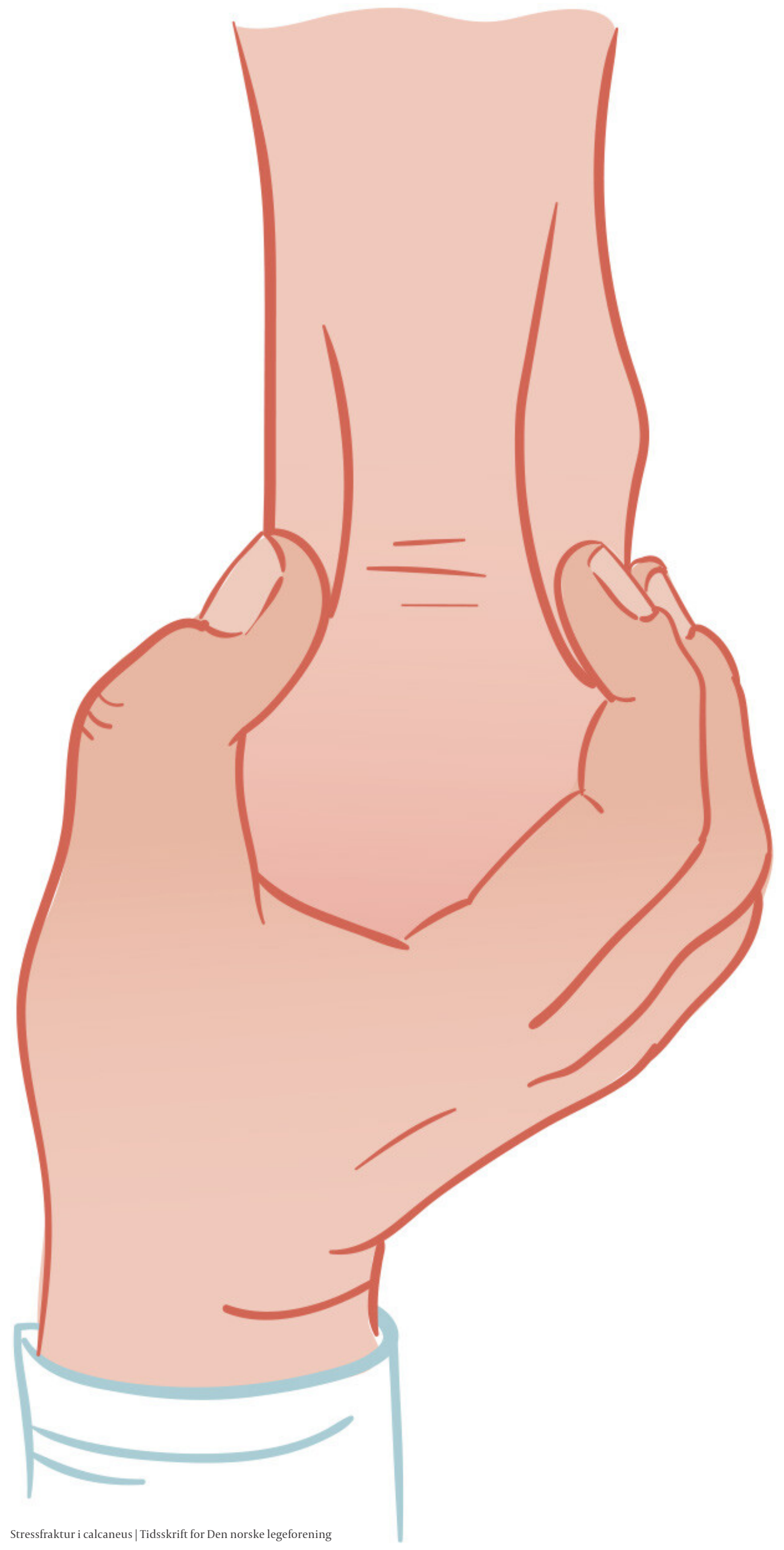




\section{Differensialdiagnoser}

Symptombildet ved stressfrakturer og stressreaksjoner i calcaneus kan ligne andre, hyppigere forekommende tilstander i hælregionen, og det kan være vanskelig å skille disse klinisk (9.). De mest aktuelle differensialdiagnosene hos voksne er bløtdelsskader som plantarfasciitt, akillestendinopati og retrocalcaneal bursitt (slimposebetennelse i hælen).

Ved plantarfasciitt er smertene lokalisert plantart, og er gjerne verst om morgenen (19). Akillestendinopati og retrocalcaneal bursitt går begge under fellesbetegnelsen akillodyni, og gir hevelse og smerter på baksiden av hælen, særlig ved tågange. Årsaken er ofte dårlig sjokkabsorberende egenskaper i hælputen, men innimellom kan akillodyni skyldes irritasjon fra en beinete utstikker posterosuperiort på calcaneus, såkalt Haglunds hæl. En

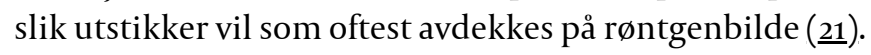

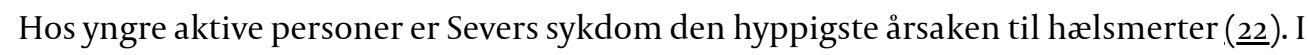
likhet med stressreaksjoner og stressfrakturer skyldes dette akkumulering av mikrotraumer etter repetitive drag fra akillessenen, men denne tilstanden oppstår kun i

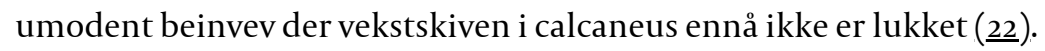

Informasjon om treningshistorikk, døgnvariasjon og eventuelt menstruasjonsforstyrrelser kan være nyttig i differensialdiagnostikken.

\section{Bildediagnostikk}

Radiologibilder kreves for å stille diagnosen stressreaksjon og stressfraktur og danner ofte grunnlag for valg av behandlingsstrategi. Ved klinisk mistanke er røntgenunders $\emptyset$ kelse førstevalg, siden denne er billig og lett tilgjengelig. Grunnet sensitivitet på 12-56 \% vil imidlertid mange stressfrakturer overses, særlig de første ukene etter symptomdebut (23). Senere røntgenbilder kan vise kallusdannelse perpendikulært til trabeklenes lengderetning i calcaneus $(3, \underline{10})$.

Ved negativ røntgenundersøkelse, men der sykehistorie og kliniske funn stadig gir mistanke om stressreaksjon, er MR førstevalg. Metoden har sensitivitet på opptil $97 \%$ og spesifisitet på opptil $99 \%$ selv i tidlige stadier $(\underline{20}, \underline{23})$ og kan i tillegg utelukke bløtdelsskader (24). . MR-undersøkelse er mindre tilgjengelig, men erfaringsmessig har de fleste pasientene hatt de aktuelle plagene over tid, og siden det er ønskelig å stille diagnosen tidligst mulig, er derfor metoden berettiget.

Stressreaksjoner presenterer seg på MR med beinmargsødem som er synlig på T2-vektede sekvenser med fettsuppresjon og STIR-sekvenser (STIR = Short T1 inversion recovery), altså MRsekvenser der vann lyser hvitt (10,24). (figur 2). En eventuell frakturlinje vil også være synlig på MR, som et mørkt signal blant annet på protontetthetsvektede sekvenser. Basert på MRfunn er det vanlig å dele slike skader inn i alvorlighetsgrad 1-4, der grad 1-3 betegnes som stressreaksjoner, mens grad 4 er stressfraktur $(\underline{10})$. $\varnothing k t$ grad er assosiert med lengre rehabiliteringstid (25). 

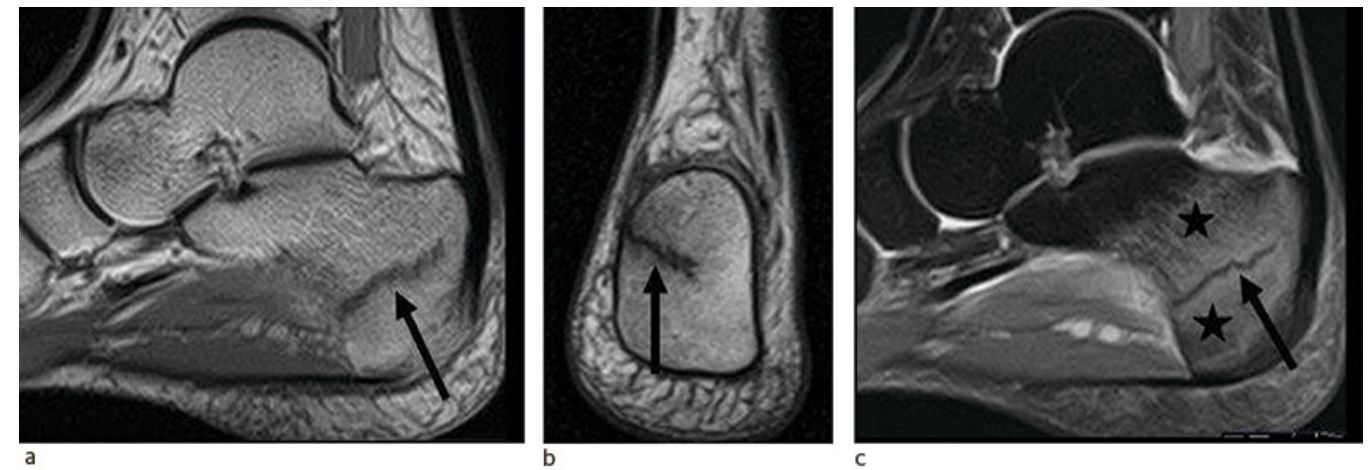

Figur 2 Stressfraktur posteriort i calcaneus fremstilles på MR som en lineær, mørk signalforandring (pil) her på protontetthetsvektet sekvens uten fettsuppresjon (a og b) og T2-vektet MR med fettsuppresjon (c). Beinmargsødem fremstilles som lyst område (stjerner) på T2-vektet MR med fettsuppresjon (c).

Beinscintigrafi ble mye brukt tidligere, men har blitt erstattet av MR grunnet høyere spesifisitet. CT fungerer ofte godt til skjelettundersøkelser, men med sensitivitet på kun 32$38 \%$ for stressreaksjoner i bein, er teknikken lite nyttig i denne sammenhengen (23). Erfaringsmessig har ultralyd både for lav sensitivitet og spesifisitet for slike skader og har derfor ingen plass i dagens utredning (23).

\section{Behandling, prognose og oppfølging}

Calcaneus er en såkalt lavrisikolokalisasjon for stressfrakturer, noe som innebærer at slike skader som regel tilheles komplikasjonsfritt uten inngrep $(\underline{6}, \underline{26})$. Dagens behandlingsalgoritme går derfor ut på å avlaste den affiserte foten før man gradvis øker belastningen igjen (므). Fravær av smerte er den viktigste indikatoren på om belastningen kan økes, og det kan være nødvendig å bruke krykker eller ortose inntil normal gange kan gjennomføres smertefritt $(\underline{6}, \underline{26})$.

Tidligere ble ikke-steroide antiinflammatoriske midler (NSAID-preparater) brukt som smertedempende medisin mot stressfrakturer. Dette frarådes i dag, ettersom disse kan forsinke tilhelingsprosessen (27.).

Under avlastningsperioden kan pasienten utføre alternative øvelser for å opprettholde sin fysiske form, som svømming, ergometersykling og eventuelt løping på antigravitasjonstredem $\varnothing l l e(\underline{10}, \underline{26})$, såfremt dette ikke gir smerter.

Gjennomsnittlig varer rehabiliteringsperioden for stressfrakturer i calcaneus 6-12 uker (3,6), men avhengig av alvorlighetsgraden kan det ta opptil tre ganger så lang tid (25). Dette understreker viktigheten av å oppdage og behandle skaden på et tidligst mulig stadium. Ved kroniske smerter selv etter forlenget konservativ behandling kan det i svært sjeldne tilfeller være aktuelt med kirurgisk behandling av stressfrakturen (프).

Parallelt med avlastningen av foten er det viktig å gjøre eventuelle ernæringsmessige korreksjoner. Lave vitamin D-verdier forekommer hyppig, særlig i vinterhalvåret, og pasienter med serumnivåer under $75 \mathrm{nmol} / \mathrm{L}$ bør supplere kostinntaket med vitamintilskudd. Videre anbefales et daglig inntak av kalsium på $1500 \mathrm{mg}$ under hele tilhelingsperioden $(\underline{28})$.

Beintetthetsmåling med røntgenbasert absorpsjonsmetri (dual-energy $x$-ray absorptiometry, DXA) kan gi nyttig informasjon om pasientens beinhelse og ernæringsstatus og om forventet tid til idrettsretur (25). Hvis pasienten har en spiseforstyrrelse, bør dette utredes videre og behandles i samarbeid med psykolog og ernæringsfysiolog (므), blant annet fordi tilstedeværelse av spiseforstyrrelser forsinker tilhelingen av stressfrakturer betydelig(25).

Ettersom tidligere stressfraktur er en stor risikofaktor for framtidig stressfraktur $(13, \underline{18})$, er det viktig at pasienten følges opp klinisk. Dersom det oppstår nye symptomer på stressfraktur, bør pasienten utredes så fort som mulig for å stille diagnosen og igangsette 
behandling tidlig. Bisfosfonater, som virker ved å hemme osteoklastaktivitet, har vist seg å kunne fremskynde tilhelingsprosessen og redusere smerten ved stressfrakturer (299). Ved andregangs stressfraktur eller førstegangs stressfraktur med mangelfull tilheling, kan man derfor forsøke bisfosfonatbehandling i samarbeid med endokrinolog (29.).

I likhet med andre differensialdiagnoser ved hælsmerter varierer symptomene på stressfrakturer i calcaneus mellom individer. Dette gjør at skaden kan nå et mer alvorlig stadium før den diagnostiseres. Det forlenger også tiden vekk fra idrett eller arbeid. Et mål bør derfor være å øke legers kjennskap til tilstanden, slik at flere tilfeller oppdages tidligere og færre tilfeller underdiagnostiseres og feilbehandles (9.).

Ettersom insidensen av stressfrakturer i calcaneus i befolkningen er lav, trenger vi forskning på store populasjoner over lengre perioder for å etablere veldokumenterte behandlingsalgoritmer. De fleste av dagens studier på området er dessverre retrospektive, noe som kan gjøre årsakssammenhenger uklare. I litteraturen som foreligger, baseres mye av de epidemiologiske dataene på militærstudier. Den populasjonen er sannsynligvis ikke representativ for hverken idrettsutøvere eller den øvrige befolkningen.

Artikkelen er fagfellevurdert.

\section{REFERENCES}

1. Warden SJ, Burr DB, Brukner PD. Stress fractures: pathophysiology, epidemiology, and risk factors. Curr Osteoporos Rep 2006; 4: 103-9. [PubMed][CrossRef]

2. Mandell JC, Khurana B, Smith SE. Stress fractures of the foot and ankle, part 1: biomechanics of bone and principles of imaging and treatment. Skeletal Radiol 2017; 46: 1021-9. [PubMed][CrossRef]

3. Weber JM, Vidt LG, Gehl RS et al. Calcaneal stress fractures. Clin Podiatr Med Surg 2005; 22: 45-54. [PubMed][CrossRef]

4. Mandell JC, Khurana B, Smith SE. Stress fractures of the foot and ankle, part 2: site-specific etiology, imaging, and treatment, and differential diagnosis. Skeletal Radiol 2017; 46: 1165-86. [PubMed] [CrossRef]

5. Bratland-Sanda S, Sundgot-Borgen J. Eating disorders in athletes: overview of prevalence, risk factors and recommendations for prevention and treatment. Eur J Sport Sci 2013; 13: 499-508. [PubMed][CrossRef]

6. Robertson GA, Wood AM. Lower limb stress fractures in sport: Optimising their management and outcome. World J Orthop 2017; 8: 242-55. [PubMed][CrossRef]

7. Reinking MF, Austin TM, Bennett J et al. Lower extremity overuse bone injury risk factors in collegiate athletes: a pilot study. Int J Sports Phys Ther 2015; 10: 155-67. [PubMed]

8. Bennell KL, Malcolm SA, Thomas SA et al. Risk factors for stress fractures in track and field athletes. A twelve-month prospective study. Am J Sports Med 1996; 24: 810-8. [PubMed][CrossRef]

9. Serrano S, Figueiredo P, Páscoa Pinheiro J. Fatigue Fracture of the Calcaneus: From Early Diagnosis to Treatment: A Case Report of a Triathlon Athlete. Am J Phys Med Rehabil 2016; 95: e79-83. [PubMed] [CrossRef]

10. Fredericson M, Jennings F, Beaulieu C et al. Stress fractures in athletes. Top Magn Reson Imaging 2006; 17:309-25. [PubMed][CrossRef]

11. Pearce CJ, Zaw H, Calder JD. Stress fracture of the anterior process of the calcaneus associated with a calcaneonavicular coalition: a case report. Foot Ankle Int 2011; 32: 85-8. [PubMed][CrossRef]

12. Taketomi S, Uchiyama E, Iwaso H. Stress fracture of the anterior process of the calcaneus: a case report. Foot Ankle Spec 2013; 6:389-92. [PubMed][CrossRef]

13. Kelsey JL, Bachrach LK, Procter-Gray E et al. Risk factors for stress fracture among young female cross-country runners. Med Sci Sports Exerc 2007; 39: 1457-63. [PubMed][CrossRef]

14. Ihle R, Loucks AB. Dose-response relationships between energy availability and bone turnover in young exercising women. J Bone Miner Res 2004; 19: 1231-40. [PubMed][CrossRef]

15. Dao D, Sodhi S, Tabasinejad R et al. Serum 25-Hydroxyvitamin D Levels and Stress Fractures in Military Personnel: A Systematic Review and Meta-analysis. Am J Sports Med 2015; 43: 2064-72.

[PubMed][CrossRef] 
16. Redman LM, Loucks AB. Menstrual disorders in athletes. Sports Med 2005; 35: 747-55. [PubMed] [CrossRef]

17. Tenforde AS, Parziale AL, Popp KL et al. Low Bone Mineral Density in Male Athletes Is Associated With Bone Stress Injuries at Anatomic Sites With Greater Trabecular Composition. Am J Sports Med 2018; 46:30-6. [PubMed][CrossRef]

18. Wright AA, Taylor JB, Ford KR et al. Risk factors associated with lower extremity stress fractures in runners: a systematic review with meta-analysis. Br J Sports Med 2015; 49: 1517-23. [PubMed][CrossRef]

19. Goulart M, O'Malley MJ, Hodgkins CW et al. Foot and ankle fractures in dancers. Clin Sports Med 2008; 27: 295-304. [PubMed][CrossRef]

20. Pegrum J, Dixit V, Padhiar N et al. The pathophysiology, diagnosis, and management of foot stress fractures. Phys Sportsmed 2014; 42: 87-99. [PubMed][CrossRef]

21. Choo YJ, Park CH, Chang MC. Rearfoot disorders and conservative treatment: a narrative review. Ann Palliat Med 2020; 9:3546-52. [PubMed][CrossRef]

22. Ogden JA, Ganey TM, Hill JD et al. Sever's injury: a stress fracture of the immature calcaneal metaphysis. J Pediatr Orthop 2004; 24: 488-92. [PubMed][CrossRef]

23. Wright AA, Hegedus EJ, Lenchik L et al. Diagnostic Accuracy of Various Imaging Modalities for Suspected Lower Extremity Stress Fractures: A Systematic Review With Evidence-Based Recommendations for Clinical Practice. Am J Sports Med 2016; 44: 255-63. [PubMed][CrossRef]

24. Spitz DJ, Newberg AH. Imaging of stress fractures in the athlete. Radiol Clin North Am 2002; 40: 313-31. [PubMed][CrossRef]

25. Nattiv A, Kennedy G, Barrack MT et al. Correlation of MRI grading of bone stress injuries with clinical risk factors and return to play: a 5-year prospective study in collegiate track and field athletes. Am J Sports Med 2013; 41: 1930-41. [PubMed][CrossRef]

26. Warden SJ, Davis IS, Fredericson M. Management and prevention of bone stress injuries in longdistance runners. J Orthop Sports Phys Ther 2014; 44: 749-65. [PubMed][CrossRef]

27. Ziltener JL, Leal S, Fournier PE. Non-steroidal anti-inflammatory drugs for athletes: an update. Ann Phys Rehabil Med 2010; 53: 278-82, 282-8. [PubMed][CrossRef]

28. Stressreaksjoner i tibia. Ernæring ved stressfrakturer 2019.

https://olympiatoppen.no/fagomrader/helse/fagstoff/stressfrakturer-i-tibia/ Lest 25.1.2021.

29. Simon MJ, Barvencik F, Luttke M et al. Intravenous bisphosphonates and vitamin D in the treatment of bone marrow oedema in professional athletes. Injury 2014; 45: 981-7. [PubMed] [CrossRef]

Publisert: 28. februar 2022. Tidsskr Nor Legeforen. DOI: 10.4045/tidsskr.21.0613

Mottatt 27.8.2021, første revisjon innsendt 26.10.2021, godkjent 16.11.2021.

Publisert under åpen tilgang CC BY-ND. Lastet ned fra tidsskriftet.no 26. april 2023. 